\title{
Exhaled nitric oxide is related to atopy, but not asthma in adolescents with bronchiolitis in infancy
}

Ingvild Bruun Mikalsen ${ }^{1 * \dagger}$, Thomas Halvorsen ${ }^{2,3+}$ and Knut Øymar ${ }^{1,2+}$

\begin{abstract}
Background: The fraction of exhaled nitric oxide (FeNO) has been suggested as a non-invasive marker of eosinophilic inflammation in asthma, but lately rather as a biomarker of atopy than of asthma itself. Asthma after bronchiolitis is common up to early adolescence, but the inflammation and pathophysiology may differ from other phenotypes of childhood asthma. We aimed to assess if FeNO was different in children with former hospitalization for bronchiolitis and a control group, and to explore whether the role of FeNO as a marker of asthma, atopy or bronchial hyperresponsiveness (BHR) differed between these two groups of children.

Methods: The study included 108 of 131 children (82\%) hospitalized for bronchiolitis in 1997-98, of whom $82(76 \%)$ had tested positive for Respiratory syncytial virus, and 90 age matched controls. The follow-up took place in 2008-2009 at 11 years of age. The children answered an ISAAC questionnaire regarding respiratory symptoms and skin prick tests, spirometry, methacholine provocation test and measurement of FeNO were performed.
\end{abstract}

Results: Analysed by ANOVA, FeNO levels did not differ between the post-bronchiolitis and control groups $(p=0.214)$. By multivariate regression analyses, atopy, height ( $p<0.001$ for both) and BHR ( $p=0.034)$, but not asthma $(p=0.805)$ or hospitalization for bronchiolitis $(p=0.359)$, were associated with FeNO in the post-bronchiolitis and control groups. The associations for atopy and BHR were similar in the post-bronchiolitis and in the control group.

Conclusion: FeNO did not differ between 11 year old children hospitalized for bronchiolitis and a control group. FeNO was associated with atopy, but not with asthma in both groups.

Keywords: Children, Eosinophilic inflammation, Respiratory syncytial virus, Wheezing

\section{Background}

Asthma in childhood is characterized by extensive heterogeneity regarding aetiology and natural history, and may present with various phenotypes probably related to different immunological, inflammatory and airway characteristics [1]. Chronic inflammation of the lower airways and bronchial hyperresponsiveness (BHR) are typical features of asthma, and markers of these factors are therefore used for diagnostic purposes and to guide treatment. The fraction of exhaled nitric oxide (FeNO) has been suggested as a non-invasive marker of eosinophilic inflammation [2], and thus a marker of asthmatic airway inflammation. Recently, FeNO has been suggested as a biomarker of atopy, and thereby a biomarker of atopic asthma

\footnotetext{
* Correspondence: miib@sus.no

${ }^{\dagger}$ Equal contributors

'Department of Paediatrics, Stavanger University Hospital, Stavanger, Norway Full list of author information is available at the end of the article
}

rather than of asthma per se [3-5], although findings have been equivocal [6-8]. Associations between FeNO and BHR, but not between FeNO and asthma have been described in atopic children [5].

Bronchiolitis in early life is an established risk factor for subsequent asthma, although the mechanisms behind are complex and heterogeneous [9]. The risk of asthma is higher after RSV negative than RSV positive bronchiolitis [10], particularly after early wheezing or bronchiolitis due to Rhinovirus (RV) [11]. While atopic asthma is associated with an eosinophilic inflammation, asthma after bronchiolitis is less related to atopy and mainly associated with viral induced wheeze and bronchial inflammation mediated by neutrophils [12-14]. Thus, markers of inflammation such as FeNO could conceivably be different in asthma after bronchiolitis than in children with atopic asthma.

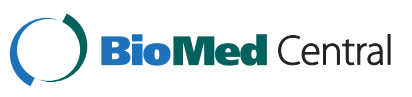


The primary aim of this study was to assess if FeNO was different in children with former hospitalization for bronchiolitis compared to a control group, and secondly to explore whether the role of FeNO as a marker of asthma, atopy or BHR differed between these two groups of children.

\section{Methods}

\section{Study design and subjects}

In this longitudinal prospective follow-up study, children below 12 months of age hospitalized for acute bronchiolitis at the university hospitals in Stavanger and Bergen (Norway) during the winter seasons 1997 and 1998 were invited to participate. Bronchiolitis was defined as an acute febrile episode of respiratory illness with tachypnea, dyspnoea, prolonged expiration and wheeze on auscultation of the chest. Exclusion criteria were previous hospitalization for wheeze or bronchiolitis, any previous use of systemic or inhaled corticosteroids, signs of bacterial infection or any other known lung disease [15]. Nasopharyngeal mucus was examined for Respiratory syncytial virus (RSV) by direct immunofluorescence in all patients (bioMèrieux, Marcy-l'Ètoile, France). Other viruses were not systematically tested for.

The children were invited to a follow-up in 2008-09 at 11 years of age. The follow-up included a questionnaire from the International Study of Asthma and Allergy in Childhood (ISAAC) [16], assessment of lung function and BHR, FeNO measurement and skin prick tests (SPT). An unselected age matched control group not hospitalized for bronchiolitis during their first year of life, reflecting the general population in the study area was recruited from 3 nearby schools.

We have previously published results showing that children in the post-bronchiolitis group had more asthma, lower lung function and higher BHR compared to controls [10].

The study was approved by the Regional Committee for Medical and Health Research Ethics West, and signed statements of informed consent were obtained from all parents.

\section{Lung function measurements}

Spirometry was performed according to established guidelines [17], using a Vmax Encore 229D spirometer (SensorMedics Inc., Anaheim, USA). Forced expiratory volume in first second $\left(\mathrm{FEV}_{1}\right)$, forced vital capacity (FVC) and forced expiratory flows at $25-75 \%$ of $\mathrm{FVC}\left(\mathrm{FEF}_{25-75}\right)$ were recorded. Except for the ratio $\mathrm{FEV}_{1} / \mathrm{FVC}$, measurements were compared to values predicted by standard reference equations and expressed as percentages of predicted $\mathrm{FEV}_{1} \%$ [18] and $\mathrm{FEF}_{25-75} \%$ [19]. BHR was assessed with methacholine provocation test (MPT), by using an inhalationsynchronised, dosimetric nebulizer, Spira Elektra $2^{\bullet}$ (Spira,
Hämeenlinna, Finland). The test was not performed if baseline $\mathrm{FEV}_{1} \%$ was $<65 \%$ predicted. Methacholine was administered in doubling doses until a $20 \%$ reduction in $\mathrm{FEV}_{1}$ was obtained or until a cumulative dose of $11.54 \mu \mathrm{mol}$ had been given. A dose response slope (DRS) was calculated as the ratio between the maximum percentage decline in $\mathrm{FEV}_{1}$ from baseline and the total administered dose of methacholine $(\% / \mu \mathrm{mol})$, and the distribution regarded as ln-normal [20].

\section{FeNO measurements}

FeNO was measured online by the single breath technique according to published guidelines [21], with an EcoMedics Exhalyzer ${ }^{\circ}$ CLD 88sp with DENOX 88 (ECO MEDICS AG, Duernten, Switzerland). NO-free air was inhaled to near total lung capacity, followed immediately by full exhalation at a constant flow of $50 \mathrm{ml} / \mathrm{s}$. FeNO was recorded as the mean value from 3 reproducible plateaus within $10 \%$ acceptability.

\section{Skin prick tests}

Skin prick tests (SPT) with the most common inhalant allergens (Dermatophagoides pteronyssinus, dog, cat dander, Cladosporium herbarium, birch, timothy, German cockroach) and food allergens (eggwhite, milk, peanut, codfish) (Soluprick ${ }^{\oplus}$, ALK Albello, Hørsholm, Denmark) for atopic sensitization in Norwegian children were performed [22]. Histamine $10 \mathrm{mg} / \mathrm{ml}$ was used as a positive control and a $0.9 \%$ saline solution as a negative control. A wheal diameter $\geq 3 \mathrm{~mm}$ larger than the negative control was defined as a positive result.

\section{Definitions}

Current asthma at 11 years of age was defined as a positive answer to the ISAAC question regarding "asthma ever" and a positive answer to at least one of the two questions:

1) wheezing or whistling in the chest or chest tightness during the preceding 12 months or ${ }^{2)}$ use of asthma medication (bronchodilators, inhaled corticosteroid, leukotriene antagonists) during the preceding 12 months.

The children in the post-bronchiolitis and control groups were divided into four sub-groups at the 11 year follow-up, according to their atopic and asthmatic status. ${ }^{1)}$ Healthy: No current asthma and no allergic sensitization. ${ }^{2)}$ Atopic non-asthmatic: Positive SPT for at least one allergen with the absence of current asthma. ${ }^{3)}$ Current atopic asthma: A combination of current asthma and atopy. ${ }^{4)}$ Current non-atopic asthma: Current asthma without atopy.

\section{Statistical methods}

Means and standard deviations (SD), medians and quartiles were estimated and reported for normally and asymmetrically distributed data, as appropriate. Group comparisons were done with Student's $t$ - test, Mann Whitney $U$-test or 
Pearson's chi-square exact test, as appropriate. FeNO (unit: parts per billion (ppb)) was regarded as ln-normally distributed and results presented as back-transformed values given as geometric means with $95 \%$ confidence intervals (CI). To study overall associations with FeNO, a two-way ANOVA was performed for the post-bronchiolitis and control groups in one common analysis. To study associations with FeNO for each sub-group, the post-bronchiolitis and control groups were analysed separately and Dunnett's test was used for post-hoc comparisons between the subgroups if the F-test was significant in the overall ANOVA analysis.

Linear regression analyses were applied to explore associations between putative explanatory variables and $\ln$ FeNO for the complete study group and for the postbronchiolitis group separately. In both models, the following variables recorded at 11 years of age were assessed: Gender, age at follow-up, height, weight, atopy, current asthma, In DRS, $\mathrm{FEV}_{1} \%, \mathrm{FEF}_{25-75} \%$, use of inhaled steroids the preceding 12 months and previous hospitalization for bronchiolitis in infancy. In the separate multivariate linear regression analysis including only subjects in the post-bronchiolitis group, RSV status (positive or negative) was also included in addition to those included for the complete study group. In all analyses, each variable was initially entered into a univariate model. Variables with p-values $<0.2$ in univariate analyses were further analysed in a backward multivariate regression model. Analyses of interaction terms were used to explore differences between the sub-groups regarding associations between explanatory variables and FeNO. When ln transforming DRS, negative values were set to 0.001 . P-values $<0.05$ were regarded as statistically significant. All analyses were two-tailed and data were analyzed using the SPSS version 18.0 statistical package (SPSS, Chicago, IL, USA).

\section{Results}

One hundred and thirty one children hospitalized for bronchiolitis during their first year of life were included, and $108(82 \%)$ consented to the follow-up at 11 years of age. Of these, 82 children (76\%) had tested positive for RSV. All completed the questionnaire and took part in SPT and lung function tests. MPT and FeNO were not performed in two and three children in the post-bronchiolitis group respectively, due to technical reasons.

In the control group, 91 of the 190 primarily invited children (48\%) completed the questionnaire and agreed to SPT and lung function test; one was excluded as further investigations indicated chronic restrictive lung disease. One child was not able to perform neither spirometry, FeNO nor MPT. In addition, MPT was not performed in two children; one had $\mathrm{FEV}_{1} \%<65 \%$ and one was not able to cooperate.

In the post-bronchiolitis group, $\mathrm{FEV}_{1} \%$ was lower in the healthy group compared to the atopic non-asthmatic group (Tables 1 and 2). There were no other differences between the four sub-groups regarding gender, age, weight, height, lung function and BHR at the 11 year follow-up within the post-bronchiolitis group and the control group, respectively (Tables 1 and 2).

Children in the post-bronchiolitis group (11.4 years; 11.0, 11.7) (median; quartiles) were slightly younger than the controls $(11.7$ years; $11.3,12.1)$ at the 11 year follow-up $(\mathrm{p}<0.001)$.

\section{FeNO}

The overall ANOVA analysis with all children included, revealed that FeNO levels did not differ between the post-bronchiolitis and control groups $(\mathrm{p}=0.214)$ (Table 3$)$. FeNO differed between the four sub-groups $(\mathrm{p}<0.001)$. FeNO levels were higher in the atopic non-asthmatic and

Table 1 Characteristics of 108 children hospitalized for bronchiolitis in their first year of life during 1997-98 at the university hospitals of Stavanger and Bergen (Norway) according to asthma and atopy at 11 years of age

\begin{tabular}{|c|c|c|c|c|c|c|c|}
\hline & $\begin{array}{l}\text { Healthy } \\
(n=64)\end{array}$ & $\begin{array}{c}\text { Atopic } \\
\text { non-asthmatic }(n=20)\end{array}$ & P-value & $\begin{array}{l}\text { Current non-atopic } \\
\text { asthma }(n=15)\end{array}$ & $\mathrm{P}$-value & $\begin{array}{l}\text { Current atopic } \\
\text { asthma }(n=9)\end{array}$ & P-value \\
\hline Boys, n (\% of group) & $30(47)$ & $14(70)$ & 0.080 & $10(67)$ & 0.252 & $6(67)$ & 0.308 \\
\hline Age at hospitalization* (months) & $3.5(2.0,6.0)$ & $4.0(1.0,10.0)$ & 0.603 & $6.0(3.0,9.0)$ & 0.052 & $5.0(4.0,9.5)$ & 0.083 \\
\hline Age at follow up* (year) & $11.4(11.0,11.8)$ & $11.3(10.9,11.5)$ & 0.182 & $11.4(10.9,11.6)$ & 0.745 & $11.6(11.3,12.2)$ & 0.410 \\
\hline Weight at follow-up ${ }^{\dagger}(\mathrm{kg})$ & $41.2(9.3)$ & $40.6(8.2)$ & 0.791 & $42.8(7.5)$ & 0.525 & $42.5(8.3)$ & 0.692 \\
\hline Height at follow-up ${ }^{\dagger}(\mathrm{cm})$ & $149.0(8.2)$ & $147.2(4.3)$ & 0.206 & $149.3(5.6)$ & 0.888 & $148.9(6.0)$ & 0.963 \\
\hline ICS, $n$ (\% of group) & 0 & 0 & & $2(13)$ & 0.034 & $7(78)$ & $<0.001$ \\
\hline$\overline{\mathrm{FEV}} \%^{+}$ & $93.9(9.3)$ & $99.7(8.9)$ & 0.014 & $97.8(9.5)$ & 0.145 & $95.8(9.5)$ & 0.555 \\
\hline $\mathrm{FEF}_{25-75} \%^{\dagger}$ & $89.9(23.9)$ & $88.6(19.1)$ & 0.819 & $86.0(22.9)$ & 0.568 & $84.4(20.2)$ & 0.514 \\
\hline$\overline{\mathrm{FEV}_{1} / \mathrm{FVC} \text { ratio }^{+}}$ & $82.8(7.5)$ & $80.6(4.9)$ & 0.221 & $79.7(7.7)$ & 0.159 & $78.8(7.3)$ & 0.135 \\
\hline DRS to methacholine ${ }^{*}$ & $6.0(1.7,25.5)$ & $4.9(1.1,13.4)$ & 0.378 & $4.1(1.5,18.1)$ & 0.910 & $4.4(2.2,13.8)$ & 0.923 \\
\hline
\end{tabular}

${ }^{*}$ Median (inter quartile range), ${ }^{\dagger}$ mean (standard deviation). ICS, inhalation corticosteroid last 12 months before follow up; FEV $\%$, forced expiratory volume in first second as percentage of predicted; $\mathrm{FEF}_{25-75} \%$, forced expiratory flow between $25-75 \%$ of the forced vital capacity (FVC); DRS, dose response slope. For missing data, see text. P-values assess comparisons with the healthy group.

Bold values indicate significance at the 0.05 level. 
Table 2 Characteristics of 90 children in an age matched control group at 11 years of age, according to asthma and atopy

\begin{tabular}{|c|c|c|c|c|c|c|c|}
\hline & $\begin{array}{l}\text { Healthy } \\
(n=51)\end{array}$ & $\begin{array}{c}\text { Atopic } \\
\text { non-asthmatic }(n=29) \\
\end{array}$ & P-value & $\begin{array}{l}\text { Current non-atopic } \\
\text { asthma }(n=5)\end{array}$ & P-value & $\begin{array}{l}\text { Current atopic } \\
\text { asthma }(n=5)\end{array}$ & P-value \\
\hline Boys, n (\%) & $31(61)$ & $16(55)$ & 0.644 & $4(80)$ & 0.640 & $4(80)$ & 0.640 \\
\hline Age at follow up* (year) & $11.8(11.4,12.2)$ & $11.4(11.0,12.1)$ & 0.081 & $12.3(11.4,12.8)$ & 0.147 & $11.8(10.9,12.0)$ & 0.502 \\
\hline Weight at follow-up ${ }^{\dagger}(\mathrm{kg})$ & $41.7(8.5)$ & $40.9(9.4)$ & 0.677 & $47.9(17.3)$ & 0.472 & $51.4(25.7)$ & 0.449 \\
\hline Height at follow-up ${ }^{\dagger}(\mathrm{cm})$ & $151.9(7.6)$ & $149.0(7.0)$ & 0.087 & $150.8(10.2)$ & 0.749 & $152.0(17.1)$ & 0.998 \\
\hline ICS, n (\%) & $1(2)$ & 0 & 1.000 & $3(60)$ & 0.001 & $4(80)$ & $<0.001$ \\
\hline $\mathrm{FEV}_{1} \%^{+}$ & $98.7(10.6)$ & $99.8(7.9)$ & 0.631 & $101.9(10.7)$ & 0.510 & $96.3(28.3)$ & 0.864 \\
\hline $\mathrm{FEF}_{25-75} \%^{\dagger}$ & $96.9(22.9)$ & $98.9(16.1)$ & 0.693 & $95.6(18.9)$ & 0.903 & $93.3(45.7)$ & 0.764 \\
\hline $\mathrm{FEV}_{1} / \mathrm{FVC}$ ratio $^{+}$ & $84.3(6.6)$ & $84.2(4.5)$ & 0.969 & $79.8(4.2)$ & 0.146 & $80.8(6.7)$ & 0.269 \\
\hline DRS to methacholine ${ }^{*}$ & $1.7(1.0,6.8)$ & $3.6(0.8,17.6)$ & 0.084 & $0.9(0.3,5.8)$ & 0.292 & $4.7(1.1,24.5)$ & 0.405 \\
\hline
\end{tabular}

${ }^{*}$ Median (inter quartile range), ${ }^{\dagger}$ mean (standard deviation). ICS, inhaled corticosteroids last 12 months before follow up; FEV ${ }_{1} \%$, forced expiratory volume in first second as percentage of predicted; $\mathrm{FEF}_{25-75} \%$, forced expiratory flow between $25-75 \%$ of the forced vital capacity (FVC) as percentage of predicted; DRS, dose response slope. For missing data, see text. P-values assess comparisons with the healthy group.

Bold values indicate significance at the 0.05 level.

the atopic asthmatic children but not in the children with non-atopic asthma compared to healthy in both the post-bronchiolitis group and in the control group (Table 3). Separate analyses for the post-bronchiolitis and the control group revealed that FeNO was higher in the atopic non-asthmatic children compared to healthy in both groups. Higher FeNO in children with atopic asthma compared to healthy was observed only in the control group (Table 4, Figure 1).

\section{Regression analyses of potential explanatory factors for In FeNO}

Atopy, weight and height were positively associated with $\ln$ FeNO by univariate linear regression analyses including all

Table 3 Analysis of variance for fractional exhaled nitric oxide (FeNO) given as In FeNO in children hospitalized for bronchiolitis $(n=105)$ during their first year of life and an age matched control group $(n=89)$ at 11 years of age

\begin{tabular}{lccc}
\hline Variable & $\mathbf{B}^{*}$ & $\mathbf{9 5 \%} \mathbf{C l}$ & P-value $^{\dagger}$ \\
\hline Main groups & & & \\
\hline Control group & 0 & Reference & \\
\hline Post-bronchiolitis group & -0.120 & $-0.309,0.070$ & 0.214 \\
\hline $\begin{array}{l}\text { Sub-groups by atopy } \\
\text { and asthma status }\end{array}$ & & & $<\mathbf{0 . 0 0 1}$ \\
\hline Healthy & 0 & Reference & \\
\hline Atopic non-asthmatic & 0.745 & $0.522,0.967$ & \\
\hline Current non-atopic asthma & 0.013 & $-0.308,0.335$ & \\
\hline Current atopic asthma & 0.651 & $0.286,1.102$ & \\
\hline Intercept ${ }^{\ddagger}$ & 2.131 & $1.970,2.291$ & \\
\hline
\end{tabular}

No significant interaction effects were observed between the variables post-bronchiolitis/control group and the four subgroups of the study, i.e. the relationships between FeNO values measured in these four subgroups were similar in the post-bronchiolitis and the control group.

${ }^{*}$ Regression coefficient; represents the amount of change of In NO induced by a change of 1 unit of the explanatory variable.

${ }^{\dagger} \mathrm{P}$-values from $\mathrm{F}$ test. ${ }^{\ddagger}$ Reference group (healthy children in the control group). Bold values indicate significance at the 0.05 level. participating children (Table 5). In the final multivariate model, atopy, ln DRS and height were independently associated with increased ln FeNO (Table 5). No interaction effects regarding $\ln$ FeNO were observed between the variables atopy and current asthma vs. no asthma, meaning that the associations between atopy and $\ln \mathrm{FeNO}$ were similar for the asthmatic and non-asthmatic children and vice versa (Table 5).

Separate regression analyses were done for children in the post-bronchiolitis group. By univariate analyses, RSV negative bronchiolitis, height, $\mathrm{FEV}_{1} \%$ predicted and atopy were positively associated with $\ln$ FeNO (Table 6). In the final multivariate model, ln DRS, height and $\mathrm{FEV}_{1} \%$ predicted were positively associated with $\ln$ FeNO (Table 6). There was a significant interaction effect between RSV negative bronchiolitis and atopy, i.e. atopy was positively associated with FeNO in the RSV negative group ( $\mathrm{B}=1.005$; 95\% CI: 0.496, 1.513; $\mathrm{p}<0.001)$, but not in the RSV positive group $(B=0.269 ; 95 \%$ CI: $-0.071,0.609$; $\mathrm{p}=0.120$ ) Table 6.

There was no significant association between RSV negative bronchiolitis and atopy (Pearson's chi square exact test $\mathrm{p}=0.304$ ), and there was no association between atopy and $\ln$ DRS ( $\mathrm{B}=0.173 ; 95 \% \mathrm{CI}:-0.409,0.755 ; \mathrm{p}=0.558)$.

\section{Discussion}

In the present study FeNO did not differ between 11 year old children hospitalized for bronchiolitis in their first year of life and an age matched control group. Secondly, atopy and BHR, but not asthma were associated with FeNO, and these associations were similar in the postbronchiolitis and in the control groups.

The guideline from the American Thoracic Society suggests that levels of FeNO below 20 ppb are less likely to indicate eosinophilic airway inflammation [2], as also reported by others [8]. In the present study, the majority of the FeNO measurements were below this limit. Infantile 
Table 4 Levels of fractional exhaled nitric oxide (FeNO) in children hospitalized for bronchiolitis and in an age matched control group, by asthma and atopic status

\begin{tabular}{|c|c|c|c|c|c|c|c|c|}
\hline & \multicolumn{4}{|c|}{ Post-bronchiolitis group $(n=105)$} & \multicolumn{4}{|c|}{ Control group $(n=89)$} \\
\hline & $\bar{N}$ & FeNO & $95 \% \mathrm{Cl}$ & P-values* vs. healthy $^{*}$ & $\bar{N}$ & FeNO & $95 \% \mathrm{Cl}$ & P-values $^{*}$ vs. healthy \\
\hline Healthy & 62 & 8.1 & $6.8,9.6$ & Reference & 50 & 7.6 & $6.4,9.1$ & Reference \\
\hline Atopic non-asthmatic & 20 & 13.6 & $10.1,18.4$ & 0.010 & 29 & 19.5 & $15.6,24.5$ & $<0.001$ \\
\hline Current non-atopic asthma & 14 & 7.2 & $5.0,10.4$ & 0.920 & 5 & 9.7 & $5.6,16.8$ & 0.781 \\
\hline Current atopic asthma & 9 & 12.3 & $7.8,19.2$ & 0.237 & 5 & 21.4 & $12.4,36.9$ & 0.002 \\
\hline
\end{tabular}

Figures are geometric means and $95 \%$ confidence intervals $(95 \% \mathrm{Cl})$. FeNO values are given as parts per billion. ${ }^{*}$ Dunnett's test.

Bold values indicate significance at the 0.05 level.

wheeze has been associated mainly with a neutrophilic inflammation, and a tendency for continued neutrophilic inflammation in this group of children could conceivably contribute to the findings of the present study [12].

The association between FeNO and atopy, but not between FeNO and asthma is in line with several other studies [3-5]. An association between FeNO and persistent wheezing has been reported for children less than 2-3 years of age $[23,24]$, but we could not confirm that this association lasts until adolescence. One of these studies did not adjust for atopy [23], while another study observed that neither personal nor a family history of atopy was associated with increased FeNO [24]. Konstantinou et al. recently described an episodic increase of $\mathrm{FeNO}$ during viral wheezing in 4-6 year old children, independent of the atopic status of the test-subjects. The increase subsided after the episodes resolved, rendering wheezers comparable to non-wheezers outside the wheezing episodes [25]. This is consistent with the low levels of FeNO in the post-bronchiolitis group in the present study. Others have reported associations between FeNO and recurrent wheeze in infants with an atopic constitution [26] and in atopic children younger than four years of age [27]. The results from the present study suggest that also for older children with a history of infant and preschool viral wheeze, atopy should be considered as an independent risk factor for increased FeNO. This is in line with a study from the Netherlands showing that FeNO can differentiate between wheezing phenotypes, but only in atopic children [28].

As previously published, lower $\mathrm{FEF}_{25-75} \%$ predicted, consistent with small airway obstruction, was observed in children in the post-bronchiolitis group than children in the control group [10]. Except for a weak positive association between $\mathrm{FEV}_{1} \%$ and $\mathrm{FeNO}$ in the post-bronchiolitis group, no associations between lung function and FeNO could be observed. FeNO may predict lung function decline in adults with severe asthma [29]. However, to our knowledge, few studies have found associations between lung function and FeNO in children [30]. Low levels of FeNO despite small airway obstruction could indicate structural explanatory mechanisms and not an ongoing eosinophilic inflammation [31].

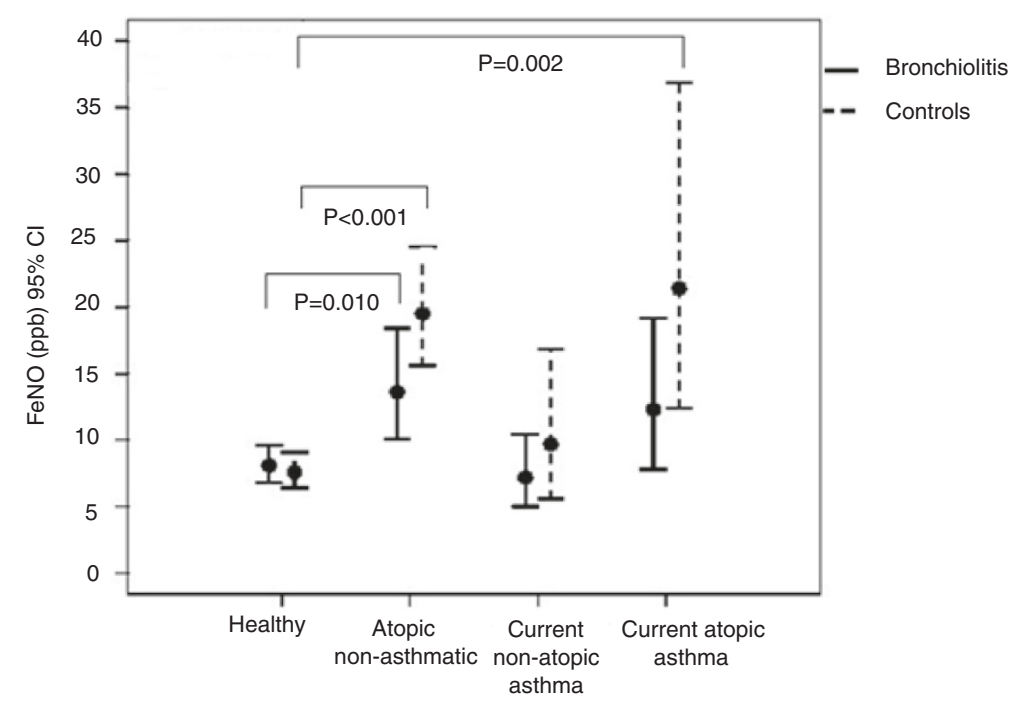

Figure 1 FeNO levels in four different sub-groups of children, split by bronchiolitis status in their first year of life. FeNO values are given as geometric mean with $95 \%$ confidence intervals (Cl). 
Table 5 Linear regression model explaining fractional exhaled nitric oxide (FeNO) given as In FeNO at 11 years of age in 105 children hospitalized for bronchiolitis and 89 children in an age matched control group, all children analysed together

\begin{tabular}{|c|c|c|c|c|c|c|c|c|c|}
\hline \multirow[b]{2}{*}{ Risk factors } & \multicolumn{3}{|c|}{ Unadjusted models } & \multicolumn{3}{|c|}{ Fully adjusted model $(\mathrm{N}=190)$} & \multicolumn{3}{|c|}{ Final model $(N=190)$} \\
\hline & $\mathrm{B}^{*}$ & $95 \% \mathrm{Cl}$ & P-value & $\mathrm{B}^{*}$ & $95 \% \mathrm{Cl}$ & P-value & $\mathrm{B}^{*}$ & $95 \% \mathrm{Cl}$ & P-value \\
\hline Hospitalization for bronchiolitis & -0.200 & $-0.408,0.008$ & 0.059 & -0.088 & $-0.276,0.101$ & 0.359 & & & \\
\hline Male gender & -0.131 & $-0.342,0.080$ & 0.223 & & & & & & \\
\hline Age at follow up (months) & 0.009 & $-0.006,0.024$ & 0.257 & & & & & & \\
\hline Height $(\mathrm{cm})$ & 0.021 & $0.007,0.034$ & 0.002 & 0.025 & $0.008,0.042$ & 0.005 & 0.027 & $0.015,0.038$ & $<0.001$ \\
\hline Weight (kg) & 0.014 & $0.004,0.025$ & 0.009 & 0.001 & $-0.012,0.014$ & 0.849 & & & \\
\hline Atopy & 0.736 & $0.539,0.934$ & $<0.001$ & 0.757 & $0.562,0.951$ & $<0.001$ & 0.773 & $0.583,0.962$ & $<0.001$ \\
\hline Current asthma & 0.035 & $-0.243,0.313$ & 0.805 & & & & & & \\
\hline Ln DRS & 0.053 & $-0.003,0.108$ & 0.062 & 0.056 & $0.008,0.105$ & 0.023 & 0.051 & $0.004,0.097$ & 0.034 \\
\hline $\mathrm{FEV}_{1} \%$ & 0.006 & $-0.004,0.016$ & 0.269 & & & & & & \\
\hline $\mathrm{FEF}_{25-75} \%$ & 0.001 & $-0.003,0.006$ & 0.597 & & & & & & \\
\hline Use of inhaled steroids preceding 12 months & 0.200 & $-0.169,0.568$ & 0.287 & & & & & & \\
\hline
\end{tabular}

No interactions were found between current asthma and atopy, atopy and DRS, atopy and hospitalization for bronchiolitis or DRS and hospitalization for bronchiolitis.

*Regression coefficient, represents the amount of change of In NO induced by a change of 1 unit of the explanatory variable.

$\mathrm{Cl}$, confidence interval; DRS, dose response slope; $\mathrm{FEV}_{1} \%$, forced expiratory volume in first second as percentage of predicted; $\mathrm{FEF}_{25-75} \%$, forced expiratory flow between $25-75 \%$ of the forced vital capacity.

Bold values indicate significance at the 0.05 level.

\section{RSV positive vs. negative bronchiolitis}

Asthma after bronchiolitis in infancy is heterogeneous and likely to represent disease entities that differ from atopic asthma in childhood. RSV is the most common virus involved in bronchiolitis, but apart from one Swedish study [32], the risk of asthma after RSV bronchiolitis has not been linked to atopy $[9,11]$. An increased risk of asthma after RSV negative vs. RSV positive bronchiolitis has been reported [10], particularly after RV bronchiolitis [11]. Wheezing with RV infections has been associated with atopy $[9,33]$, although we found no association between atopy and a history of RSV negative bronchiolitis. Temporarily reduced FeNO has been found in children hospitalized for RSV bronchiolitis. Although the

Table 6 Linear regression model explaining fractional exhaled nitric oxide (FeNO) given as In FeNO at 11 years of age in 105 children hospitalized for bronchiolitis

\begin{tabular}{|c|c|c|c|c|c|c|c|c|c|}
\hline \multirow[b]{2}{*}{ Risk factors } & \multicolumn{3}{|c|}{ Unadjusted models } & \multicolumn{3}{|c|}{ Fully adjusted model $(\mathrm{N}=103)$} & \multicolumn{3}{|c|}{ Final model $(\mathrm{N}=103)$} \\
\hline & $\mathrm{B}^{*}$ & $95 \% \mathrm{Cl}$ & P-value & $\mathrm{B}^{*}$ & $95 \% \mathrm{Cl}$ & P-value & $\mathrm{B}^{*}$ & $95 \% \mathrm{Cl}$ & P-value \\
\hline RSV negative bronchiolitis & 0.335 & $0.019,0.651$ & 0.038 & 0.010 & $-0.337,0.357$ & 0.957 & 0.009 & $-0.336,0.354$ & 0.958 \\
\hline Male gender & -0.112 & $-0.388,0.164$ & 0.423 & & & & & & \\
\hline Age at follow-up (months) & -0.004 & $-0.277,0.269$ & 0.977 & & & & & & \\
\hline Height $(\mathrm{cm})$ & 0.024 & $0.005,0.043$ & 0.015 & 0.025 & $0.000,0.050$ & 0.053 & 0.024 & $0.007,0.041$ & 0.006 \\
\hline Weight (kg) & 0.015 & $0.001,0.030$ & 0.058 & -0.001 & $-0.021,0.020$ & 0.946 & & & \\
\hline Atopy & 0.510 & $0.219,0.802$ & 0.001 & 0.269 & $-0.073,0.611$ & 0.121 & 0.269 & $-0.071,0.609$ & 0.120 \\
\hline Current asthma & -0.033 & $-0.366,0.299$ & 0.977 & & & & & & \\
\hline Ln DRS & 0.061 & $-0.025,0.148$ & 0.161 & 0.094 & $0.015,0.173$ & 0.020 & 0.094 & $0.017,0.172$ & 0.018 \\
\hline $\mathrm{FEV}_{1} \%$ & 0.015 & $0.000,0.029$ & 0.044 & 0.018 & $0.004,0.032$ & 0.013 & 0.018 & $0.004,0.031$ & 0.012 \\
\hline $\mathrm{FEF}_{25-75} \%$ & 0.002 & $-0.005,0.008$ & 0.610 & & & & & & \\
\hline Use of inhaled steroids preceding 12 months & 0.003 & $-0.494,0.488$ & 0.990 & & & & & & \\
\hline \multicolumn{10}{|l|}{ Interaction } \\
\hline RSV negative bronchiolitis $\times$ atopy & & & & 0.736 & $0.125,1.346$ & 0.019 & 0.736 & $0.128,1.343$ & 0.018 \\
\hline
\end{tabular}

No interactions were found between current asthma and atopy, atopy and In DRS or In DRS and RSV negative bronchiolitis. There was an interaction between RSV negative bronchiolitis and atopy, and the final model therefor includes both the interaction effect and its main variables (atopy and RSV negative bronchiolitis). ${ }^{*}$ Regression coefficient, represents the amount of change of In NO induced by a change of 1 unit of the explanatory variable.

$\mathrm{Cl}$, confidence interval; DRS, dose response slope; $\mathrm{FEV}_{1} \%$, forced expiratory volume in first second as percentage of predicted; $\mathrm{FEF}_{25-75} \%$, forced expiratory flow between $25-75 \%$ of the forced vital capacity.

Bold values indicate significance at the 0.05 level. 
explanatory mechanisms are not known, it has been speculated if the absence of eosinophilic inflammation during the acute bronchiolitis may be involved [34]. The present study showed that previous RSV negative bronchiolitis was associated with higher FeNO, but not after adjusting for DRS, atopy and height.

The interaction effect observed between atopy and RSV negative bronchiolitis may suggest that the influence from atopy on FeNO is different for children with former RSV positive than RSV negative bronchiolitis. Our results could indicate that atopy was more linked to FeNO at 11 years of age in children with former RSV negative than RSV positive bronchiolitis. However, the number of participants was limited and there was a similar and near significant tendency also for children with a history of RSV positive bronchiolitis, suggesting that the results should be interpreted with caution.

\section{FeNO and bronchial hyperresponsiveness}

In the present study, DRS to methacholine was independently and positively associated with FeNO by the multivariate regression analyses including all children and also in the separate regression analyses including only children in the post-bronchiolitis group.

A similar association was found by Franklin et al., but only in atopic children [5]. The Copenhagen birth cohort study observed an association between FeNO and BHR, but underlined that this association was independent of asthma symptoms [35]. We found a similar association between DRS and FeNO for atopic and non-atopic children. In the present and in another recent study from the same population, asthma or atopy was not associated with BHR, although BHR was higher in the postbronchiolitis group [10]. The relationship between NO metabolism and BHR in asthma is complex [36]. The ATS guideline underlines that studies report inconsistent associations and low correlations between FeNO and BHR, and that BHR, airway inflammation and FeNO belong to different domains [2]. A Norwegian twin study observed that common genetic effects could explain the association between FeNO and BHR, suggesting that FeNO is not related to BHR per se [37]. Moreover, BHR measured by direct provocation tests using methacholine or histamine reflects structural airway changes, compared to indirect provocation tests such as adenosine monophosphate or exercise which probably better reflects airway inflammation [38].

\section{Strengths and limitations}

The main strengths of this study were the prospective design, the long follow-up period and the high attendance rate of $82 \%$ of those originally included with bronchiolitis. However, the number of participants in the various sub-groups was relatively low, reducing the statistical power and complicating the interpretations of the results. This could impact the lack of interaction between the subgroups and between the post-bronchiolitis and control groups in the overall ANOVA analysis. In addition, the number of children in the RSV negative group was small and the results regarding this group must be interpreted with caution.

The children in the control group were slightly older than children in the post-bronchiolitis group at follow-up, but this should not influence the predicted values regarding lung function. However, a selection bias among those who consented cannot be excluded.

RSV was analyzed by direct immunofluorescence and not based on nucleic acid amplification such as reverse polymerase chain reaction (PCR). PCR is considered more sensitive and specific than direct immunofluorescence [39].

\section{Conclusion}

In this study, FeNO did not differ between 11 year old children hospitalized for bronchiolitis in infancy and an age matched control group. FeNO was associated with atopy, but not with asthma in both groups of children. This may suggest that FeNO may be unrelated to the pathophysiology of asthma after bronchiolitis. The results could also reflect that airway inflammation is rare in children 11 years after bronchiolitis.

\begin{abstract}
Abbreviations
BHR: Bronchial hyperresponsiveness; FeNO: Exhaled nitric oxide; RSV: Respiratory syncytial virus; ISAAC: International Study of Asthma and Allergy in Childhood; SPT: Skin prick test; MPT: Methacholine provocation test; ICS: Inhaled corticosteroid; FEV $1 \%$ : Forced expiratory volume in first second as percentage of predicted; $\mathrm{FEF}_{25-75} \%$ : Forced expiratory flow between $25-75 \%$ of the forced vital capacity; FVC: Forced vital capacity as percentage of predicted; DRS: Dose response slope; PCR: Polymerase chain reaction
\end{abstract}

\section{Competing interests}

The authors declare that they have no competing interests.

\section{Authors' contributions}

IBM: Participated in drafting the study, performed the sampling of data at Stavanger University Hospital, performed the statistical analyses, wrote a draft and completed the manuscript. TH: Contributed to the draft of the study, was responsible for the sampling of data at Haukeland University Hospital, and contributed significantly to the writing of the manuscript. $K \varnothing$ : Supervised all parts of the study, the drafting, registration of data, analyses and contributed significantly to the writing of the manuscript. All authors read and approved the final manuscript.

\section{Acknowledgements}

We appreciate the statistical advices given by Geir Egil Eide and Bjørn Henrik Auestad.

\section{Author details}

'Department of Paediatrics, Stavanger University Hospital, Stavanger, Norway. ${ }^{2}$ Department of Clinical Science, University of Bergen, Bergen, Norway.

${ }^{3}$ Department of Paediatrics, Haukeland University Hospital, Bergen, Norway.

Received: 13 December 2012 Accepted: 12 November 2013

Published: 17 November 2013 


\section{References}

1. Martinez FD: The origins of asthma and chronic obstructive pulmonary disease in early life. Proc Am Thorac Soc 2009, 6:272-277.

2. Dweik RA, Boggs PB, Erzurum SC, Irvin CG, Leigh MW, Lundberg JO, Olin AC, Plummer AL, Taylor DR: An official ATS clinical practice guideline: interpretation of exhaled nitric oxide levels (FENO) for clinical applications. Am J Respir Crit Care Med 2011, 184:602-615.

3. Scott M, Raza A, Karmaus W, Mitchell F, Grundy J, Kurukulaaratchy RJ, Arshad SH, Roberts G: Influence of atopy and asthma on exhaled nitric oxide in an unselected birth cohort study. Thorax 2010, 65:258-262.

4. Sachs-Olsen C, Lodrup Carlsen KC, Mowinckel P, Haland G, Devulapalli CS, Munthe-Kaas MC, Carlsen KH: Diagnostic value of exhaled nitric oxide in childhood asthma and allergy. Pediatr Allergy Immunol 2010, 21:213-221.

5. Franklin PJ, Turner SW, Le Souef PN, Stick SM: Exhaled nitric oxide and asthma: complex interactions between atopy, airway responsiveness, and symptoms in a community population of children. Thorax 2003, 58:1048-1052.

6. Rouhos A, Kainu A, Karjalainen J, Lindqvist A, Piirila P, Sarna S, Haahtela T, Sovijarvi AR: Atopic sensitization to common allergens without symptoms or signs of airway disorders does not increase exhaled nitric oxide. Clin Respir J 2008, 2:141-148.

7. Kercsmar C: Exhaled nitric oxide in the diagnosis and management of childhood asthma. Ther Adv Respir Dis 2010, 4:71-82.

8. Malmberg LP, Turpeinen H, Rytila P, Sarna S, Haahtela T: Determinants of increased exhaled nitric oxide in patients with suspected asthma. Allergy 2005, 60:464-468.

9. Stein RT: Long-term airway morbidity following viral LRTI in early infancy: recurrent wheezing or asthma? Paediatr Respir Rev 2009, 10(Suppl 1):29-31.

10. Mikalsen IB, Halvorsen T, Oymar K: The outcome after severe bronchiolitis is related to gender and virus. Pediatr Allergy Immunol 2012, 23:391-398.

11. Jackson DJ: The role of rhinovirus infections in the development of early childhood asthma. Curr Opin Allergy Clin Immunol 2010, 10:133-138.

12. Marguet C, Jouen-Boedes F, Dean TP, Warner JO: Bronchoalveolar cell profiles in children with asthma, infantile wheeze, chronic cough, or cystic fibrosis. Am J Respir Crit Care Med 1999, 159:1533-1540.

13. Stevenson EC, Turner G, Heaney LG, Schock BC, Taylor R, Gallagher T, Ennis $M$, Shields MD: Bronchoalveolar lavage findings suggest two different forms of childhood asthma. Clin Exp Allergy 1997, 27:1027-1035.

14. Marguet C, Bocquel N, Benichou J, Basuyau JP, Hellot MF, Couderc L, Mallet $E$, Mace $B$ : Neutrophil but not eosinophil inflammation is related to the severity of a first acute epidemic bronchiolitis in young infants. Pediatr Allergy Immunol 2008, 19:157-165.

15. Øymar $\mathrm{K}$, Halvorsen T, Aksnes L: Mast cell activation and leukotriene secretion in wheezing infants. Relation to respiratory syncytial virus and outcome. Pediatr Allergy Immunol 2006, 17:37-42.

16. Committee IS: Worldwide variation in prevalence of symptoms of asthma, allergic rhinoconjunctivitis, and atopic eczema: ISAAC. The International Study of Asthma and Allergies in Childhood (ISAAC) Steering Committee. Lancet 1998, 351:1225-1232.

17. American Thoracic Society: Standardization of spirometry, 1994 update. Am J Respir Crit Care Med 1995, 152:1107-1136.

18. Quanjer PH, Borsboom GJ, Brunekreef B, Zach M, Forche G, Cotes JE, Sanchis J, Paoletti P: Spirometric reference values for white European children and adolescents: Polgar revisited. Pediatr Pulmonol 1995, 19:135-142.

19. Wang X, Dockery DW, Wypij D, Fay ME, Ferris BG Jr: Pulmonary function between 6 and 18 years of age. Pediatr Pulmonol 1993, 15:75-88.

20. O'Connor G, Sparrow D, Taylor D, Segal M, Weiss S: Analysis of dose-response curves to methacholine. An approach suitable for population studies. Am Rev Respir Dis 1987, 136:1412-1417.

21. American Thoracic Society, European Respiratory Society: ATS/ERS recommendations for standardized procedures for the online and offline measurement of exhaled lower respiratory nitric oxide and nasal nitric oxide, 2005. Am J Respir Crit Care Med 2005, 171:912-930.

22. Bakken HN, Nafstad P, Bolle R, Nystad W: Skin sensitization in school children in northern and southern Norway. J Asthma 2007, 44:23-27.

23. Debley JS, Stamey DC, Cochrane ES, Gama KL, Redding GJ: Exhaled nitric oxide, lung function, and exacerbations in wheezy infants and toddlers. J Allergy Clin Immunol 2010, 125:1228-1234. e1213.

24. Ghdifan S, Verin E, Couderc L, Lubrano M, Michelet I, Marguet C: Exhaled nitric oxide fractions are well correlated with clinical control in recurrent infantile wheeze treated with inhaled corticosteroids. Pediatr Allergy Immunol 2010, 21:1015-1020
25. Konstantinou GN, Xepapadaki P, Manousakis E, Makrinioti H, Kouloufakou-Gratsia K, Saxoni-Papageorgiou P, Papadopoulos NG: Assessment of airflow limitation, airway inflammation, and symptoms during virus-induced wheezing episodes in 4- to 6-year-old children. J Allergy Clin Immunol 2013, 131:87-93. e81-85.

26. Gabriele C, Nieuwhof EM, Van Der Wiel EC, Hofhuis W, Moll HA, Merkus PJ, De Jongste JC: Exhaled nitric oxide differentiates airway diseases in the first two years of life. Pediatr Res 2006, 60:461-465.

27. Moeller A, Diefenbacher C, Lehmann A, Rochat M, Brooks-Wildhaber J, Hall $\mathrm{GL}$, Wildhaber $\mathrm{JH}$ : Exhaled nitric oxide distinguishes between subgroups of preschool children with respiratory symptoms. J Allergy Clin Immunol 2008, 121:705-709.

28. van der Valk RJ, Caudri D, Savenije O, Koppelman GH, Smit HA, Wijga AH, Postma DS, Kerkhof M, Brunekreef B, de Jongste JC: Childhood wheezing phenotypes and FeNO in atopic children at age 8. Clin Exp Allergy 2012, 42:1329-1336.

29. van Veen IH, Ten Brinke A, Sterk PJ, Sont JK, Gauw SA, Rabe KF, Bel EH: Exhaled nitric oxide predicts lung function decline in difficult-to-treat asthma. Eur Respir J 2008, 32:344-349.

30. Steerenberg PA, Janssen NA, de Meer G, Fischer PH, Nierkens S, van Loveren H, Opperhuizen A, Brunekreef B, van Amsterdam JG: Relationship between exhaled NO, respiratory symptoms, lung function, bronchial hyperresponsiveness, and blood eosinophilia in school children. Thorax 2003, 58:242-245.

31. Turner SW, Young S, Landau LI, Le Souef PN: Reduced lung function both before bronchiolitis and at 11 years. Arch Dis Child 2002, 87:417-420

32. Sigurs N, Aljassim F, Kjellman B, Robinson PD, Sigurbergsson F, Bjarnason R, Gustafsson PM: Asthma and allergy patterns over 18 years after severe RSV bronchiolitis in the first year of life. Thorax 2010, 65:1045-1052.

33. Jartti T, Kuusipalo H, Vuorinen T, Soderlund-Venermo M, Allander T, Waris M, Hartiala J, Ruuskanen O: Allergic sensitization is associated with rhinovirus-, but not other virus-, induced wheezing in children. Pediatr Allergy Immunol 2010, 21:1008-1014.

34. Gadish T, Soferman R, Merimovitch T, Fireman E, Sivan Y: Exhaled nitric oxide in acute respiratory syncytial virus bronchiolitis. Arch Pediatr Adolesc Med 2010, 164:727-731.

35. Malby Schoos AM, Chawes BL, Bonnelykke K, Bisgaard H: Fraction of exhaled nitric oxide and bronchial responsiveness are associated and continuous traits in young children independent of asthma. Chest 2012, 142:1562-1568.

36. Meurs H, Maarsingh H, Zaagsma J: Arginase and asthma: novel insights into nitric oxide homeostasis and airway hyperresponsiveness. Trends Pharmacol Sci 2003, 24:450-455.

37. Lund MB, Kongerud J, Nystad W, Boe J, Harris JR: Genetic and environmental effects on exhaled nitric oxide and airway responsiveness in a population-based sample of twins. Eur Respir J 2007, 29:292-298.

38. Cockcroft DW, Davis BE: Diagnostic and therapeutic value of airway challenges in asthma. Curr Allergy Asthma Rep 2009, 9:247-253.

39. Popow-Kraupp T, Aberle JH: Diagnosis of respiratory syncytial virus infection. Open Microbiol J 2011, 5:128-134.

doi:10.1186/1471-2466-13-66

Cite this article as: Mikalsen et al: Exhaled nitric oxide is related to atopy, but not asthma in adolescents with bronchiolitis in infancy. BMC Pulmonary Medicine 2013 13:66.

\section{Submit your next manuscript to BioMed Central and take full advantage of:}

- Convenient online submission

- Thorough peer review

- No space constraints or color figure charges

- Immediate publication on acceptance

- Inclusion in PubMed, CAS, Scopus and Google Scholar

- Research which is freely available for redistribution 